\title{
AEROBIC BACTERIA ASSOCIATED WITH ENDOMETERITIS OF SLAUGHTERED SHEEP AND GOATS IN KAFR EL-SHEIKH GOVERNORATE
}

\author{
T. H. S. Badier and G.. I . Mazyad \\ Vet. Lab., Animal Health Research Institute
}

\begin{abstract}
This study was done at Kafr El-Sheikh Governorate on uteri of both slaughtered sheep (100) and goats (100) in the abattoir during December 2008 and January 2009 and post-mortem was operated to examine these obtained uteri, those divided into two groups (non purulent and purulent uteri) the uterine swabs were collected from (40) sheep and (40) goats and cultivation on specific and selective media to isolate the aerobic bacterial microorganisms associated with endometritis of these animals. The incidence of non-purulent and purulent uteri were $85 \%$ and $15 \%$ in sheep and $80 \%$ an $20 \%$ in goats, respectively.

Also, this study illustrated that the incidence of bacterial isolates sheep (40) and goats (40) which had non purulent and purulent uteri was $62.5 \%, 37.5 \%$ and, $50 \%$ and $50 \%$, respectively.

The incidence of bacterial strains was 50\% (Staphilococcus aureus), 12.5\% (Streptococcus viridans), 2.5 (Campylobacter fetus), 50\% (Escherichia coli), $2.5 \%$ (Proteus vulgaris) 5\% (Pseudomonas aeruginosa) in sheep, but in goats this incidence was 25\% (Staph. aureus), $12.5 \%$ (Strept. viridans), $12.5 \%$ (Campylobacer fetus), $37.5 \%$ (E. coli) and $12.5 \%$ (Proteus vulgaris).
\end{abstract}


The rate of the isolated bacterial strains was $22.99 \%$ (Staph. aureus), 7.46\% (Strept. viridans), $14.93 \%$ (Campylobacter fetus), $22.39 \%$ (E. coli), $11.40 \%$ (Proteus vulgaris) and 2.99\% (Pseudomonas aeruginosa) in non purulent uteri sheep while in purulent uteri of sheep this rate was $7.46 \%$ (Staph. aureus), 0\% (Strept. viridans) 0\% (Campylobcter fetus), 7.46\%(E. coli),2.99\% (Proteus vulgaris)and 0\% (Ps. aeruginosa). Also, this rate in goats was 20\% (Staph. aureus), $12.5 \%$ (Strept. viridans), $12.5 \%$ (Campylobacter fetus), 25\% (E. coli), 10\% (Proteus vulgaris), and 0\% (Ps. aeruginosa) in non purulent uteri while it was 5\% (Staph. aureus) 0\% (Strept. viridans), 0\% [Campylobacter fetus), 12.5 (E. coli), 2.5\% (Proteus vulgaris) and 0\% (Ps. aeruginosa).

This study revealed that all isolates of Staph. aureus and Strept. viridans were more sensitive to erythromycin, chloromphenicol, gentamycin, streptomycin, neomycin, oxytetracyclin and enerofloxacin, but campylobacter fetus isolates were sensitive to gentamycin, streptomycin and enerofloxacin, while, isolates of E. coli and Proteus vulgaris were only sensitive to gentamycin and enrofloxacin. On the other hand, the isolates of Ps. aeruginosa were only sensitive to enerofloaxcain and resistant to remained used antibiotics in this work.

\section{INTRODUCTION}

The small ruminant animals (sheep and goats) are considered as a source of protein and milk for human consumption and wool production used by human.

Ewes and goats should have complete normal genital organs useful for production of off springs (Blood and Handerson, 1974). 
Bacterial infections of sheep and goats uteri cause to endometritis with several types of inflammation and lead to non pregnant and dead fetus (Blood and Handreson, 1974, Martin, and Aiken, 2000 and Donkin and Boyazogiu, 2004).

The bacterial microorganisms are Staphylococcus spp., Streptococcus spp. Corynebacterium spp., E. coli, Pseudomonas aureuginosa, Proteus spp., Campylobacter fetus, Khebsiella and Enterobacter cloacae which were reported as bacterial causes of enodmetritis of sheep and goats (Nizamani et al., 2002 and Sokkar et al., 2007).

So this study was done to isolate various bacterial agents from uterine swab samples of sheep and goats to be identified, and recorded its incidence and rate.

\section{MATERIAL AND METHODS}

This study was carried on uteri of slaughtered sheep (100) and goats (100) in abattoirs in Kafr El-Sheikh governorate during December 2008 and January, 2009.

These uteri were taken as soon as possible on ice box to laboratory under aseptic condition to decide the presence of inflammation and divided into two groups (non purulent, and purulent uteri) as shown in Tables $(1,2,3)$.

Then take swab from each uterus under aseptic condition. These samples were cultivated onto specific media (peptone water, Loffler's blood agar, nutrient agar, baired barker, McConeky agar and Citramide agar media) and incubated at $37^{\circ} \mathrm{C}$ for 24 hours (Bailley and Scott, 1974). 
Morphological character of stained films were examined by microscope (Cruickshank et al., 1975).

The obtained bacterial isolates were classified and confirmed by biochemical and serological tests (Cruickshank et al., 1975 and Bailley and Soctt 1974).

The agglutination plate test (antiserum was obtained from Vaccine and Serum Research Institute, Abbasia) applied to report Staphylococcus spp. and biochemical tests (urease, triple sugar, indole, vogus-prouskaur test) were done (Baily and Scott, 1974).

Sensitivity tests for some obtained bacterial strains were applied by using method of antibiograms to clear their sensitivity to gentamycin, streptomycin, chloramphenicol, neomycin, oxytetracyclin, (Bailey and Scott, 1974 and Ernest et al., 1976).

Table (1): The post mortem examination of ewe's uterus.

\begin{tabular}{||c||c|c|}
\hline \multirow{2}{*}{ Post mortem examination of uteri } & \multicolumn{2}{|c|}{ Findings observation } \\
\cline { 2 - 3 } & No & $\%$ \\
\hline \hline Non purulent uterus \\
Purulent uterus & 85 & 85 \\
\multicolumn{1}{|c|}{ Total } & 15 & 15 \\
\hline \hline
\end{tabular}

Table (2): The post mortem examination of goat's uterus.

\begin{tabular}{||c|c|c||}
\hline \multirow{2}{*}{ Post mortem examination of uteri } & \multicolumn{2}{|c|}{ Findings observation } \\
\cline { 2 - 3 } & No & \% \\
\hline \hline Non purulent uterus \\
Purulent uterus & 80 & 80 \\
& 20 & 20 \\
\hline \hline \multicolumn{1}{|c|}{ Total } & $\mathbf{1 0 0}$ & $\mathbf{1 0 0}$ \\
\hline
\end{tabular}

Kafrelsheikh Vet. Med. J. Vol. 7 No. 1 (2009) 
Aerobic Bacteria Associated With Endometeritis Of ...

Table (3): The post mortem examination of uterus from sheep and goats which used for bacteriological isolation.

\begin{tabular}{|c|c|c|c|c|}
\hline \multirow{2}{*}{ Post mortem examination of uterus } & \multicolumn{2}{|c|}{ Sheep } & \multicolumn{2}{|c|}{ Goat } \\
\hline & No. & $\%$ & No. & $\%$ \\
\hline Non purulent & 25 & 62.5 & 20 & 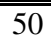 \\
\hline Purulent & 15 & 37.5 & 20 & 50 \\
\hline Total & 40 & 100 & 40 & 100 \\
\hline
\end{tabular}

\section{RESULTS}

Table (4): The incidence of isolated bacterial strains from sheep (40).

\begin{tabular}{|c|c|c|c|c|c|c|c|c|c|c|c|c|c|}
\hline \multirow{3}{*}{$\begin{array}{c}\text { Post mortem } \\
\text { examination } \\
\text { of uteri }\end{array}$} & \multirow{3}{*}{$\stackrel{\text { हैं }}{\circ}$} & \multicolumn{12}{|c|}{ Bacterial isolates } \\
\hline & & \multicolumn{2}{|c|}{ Staph. aureus } & \multicolumn{2}{|c|}{$\begin{array}{c}\text { Strept. } \\
\text { viridans }\end{array}$} & \multicolumn{2}{|c|}{\begin{tabular}{|c|} 
Camylobacter \\
fetus
\end{tabular}} & \multicolumn{2}{|c|}{ E. coli } & \multicolumn{2}{|c|}{$\begin{array}{l}\text { Proteus } \\
\text { vulgaris }\end{array}$} & \multicolumn{2}{|c|}{$\begin{array}{c}\text { Ps. } \\
\text { aurrusnosa }\end{array}$} \\
\hline & & No. & $\%$ & No. & $\%$ & No. & $\%$ & No. & $\%$ & No. & $\%$ & No. & $\%$ \\
\hline Non purulent & 25 & 15 & 37.5 & $\overline{5}$ & 12.5 & 10 & 25 & 15 & 37.5 & 8 & 20 & 2 & 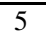 \\
\hline Purulent & 15 & 5 & 12.5 & 0 & 0 & 0 & 0 & 5 & 12.5 & 2 & 5 & 0 & 0 \\
\hline Total & $\overline{40}$ & 20 & $\overline{\mathbf{5 0}}$ & 5 & $\overline{12.5}$ & $\overline{10}$ & 25 & 20 & $\begin{array}{l}\mathbf{5 0} \\
\end{array}$ & $\overline{10}$ & 2.5 & 2 & $\overline{5}$ \\
\hline
\end{tabular}

This Table (4) illustrate that the number and incidence of isolated bacterial strains from non purulent uteri of sheep was 15 (37.5\%) Staph. aureus, 5 (12.5\%) Strept. viridans, 10 (25\%) Campylobacter fetus, 15 (37.5\%) E. coli, 8 (20\%) Proteus vulgaris and 2 (5\%) Ps. aeruginosa, while, they were $5(12.5 \%)$ Staph. aureus, 0 (0\%) Strept. viridans, 0 (0\%) Campylobacter fetus, 5 (12.5\%) E. coli, 2 (5\%) Proteus vulgaris and $0(\%)$ Ps. aeruginosa which isolated from purulent uteri of sheep.

Table (5): The rate of isolated bacterial strains from uterus of sheep.

\begin{tabular}{||l||c|c||c|c||c|c||}
\hline \multirow{2}{*}{\multicolumn{1}{|c||}{ Microorganisms }} & \multicolumn{2}{c||}{ Total } & \multicolumn{2}{c||}{ Non Purulent uterus } & \multicolumn{2}{c||}{ Purulent uterus } \\
\cline { 2 - 7 } & No. & $\mathbf{\%}$ & No. & \% & No. & \% \\
\hline \hline Staph. aureus & 20 & 29.85 & 15 & 22.39 & 5 & 7.46 \\
Strept. viridans & 5 & 7.46 & 5 & 7.46 & 0 & 0 \\
Campylobacter fetus & 10 & 14.93 & 10 & 14.93 & 0 & 0 \\
E. coli & 20 & 29.85 & 15 & 22.39 & 5 & 7.46 \\
Proteus vulgaris & 10 & 14.93 & 8 & 11.40 & 2 & 2.99 \\
Ps. aeruginosa & 2 & 2.98 & 2 & 2.99 & 0 & 0 \\
\hline \hline \multicolumn{1}{|c|}{ Total } & $\mathbf{6 7}$ & $\mathbf{1 0 0}$ & $\mathbf{5 5}$ & $\mathbf{8 2 . 0 9}$ & $\mathbf{1 2}$ & $\mathbf{1 7 . 9 1}$ \\
\hline
\end{tabular}

Kafrelsheikh Vet. Med. J. Vol. 7 No. 1 (2009) 
Table (5) revealed that the number and rate of isolated bacterial strains 15 (22.39\%) Staph. aureus, 5 (7.46\%) (Strept. viridans, 10 (14.93\%) Campylobacter fetus, 15 (22.39\%), E. coli, 8 (11.40\%) Proteus vulgaris, and 2 (2.99\%), Ps. aeruginosa from non Purulent uteri of sheep, while, they $5(7.46 \%)$ Staph.aureus, 0(0\%)Strept. viridans, 0 (0\%) (Campylobacter fetus), 5 (7.46\%), E. coli, 2 (2.99\%) Proteus vulgaris and 0 (0\%) Ps. aeruginosa from purulent uteri of sheep.

Table (6): The incidence of isolated bacterial strains from uteri of goats (40).

\begin{tabular}{|c|c|c|c|c|c|c|c|c|c|c|c|c|c|}
\hline \multirow{3}{*}{$\begin{array}{c}\text { Post mortem } \\
\text { examination } \\
\text { of uteri }\end{array}$} & \multirow{3}{*}{ 苞 } & \multicolumn{12}{|c|}{ Bacterial isolates } \\
\hline & & \multicolumn{2}{|c|}{$\begin{array}{l}\text { Staph. } \\
\text { aureus }\end{array}$} & \multicolumn{2}{|c|}{$\begin{array}{c}\text { Strept. } \\
\text { viridans }\end{array}$} & \multicolumn{2}{|c|}{$\begin{array}{c}\text { Campylobac } \\
\text { ter fetus }\end{array}$} & \multicolumn{2}{|c|}{ E. coli } & \multicolumn{2}{|c|}{$\begin{array}{l}\text { Proteus } \\
\text { vulgaris }\end{array}$} & \multicolumn{2}{|c|}{$\begin{array}{c}\text { Ps. } \\
\text { Aeruginosa }\end{array}$} \\
\hline & & No. & $\%$ & No. & $\%$ & No. & $\%$ & No. & $\%$ & No. & $\%$ & No. & $\%$ \\
\hline Non purulent & 32 & 8 & 20 & 5 & 12.5 & 5 & 12.5 & 10 & 25 & 4 & 10 & 0 & 0 \\
\hline Purulent & 8 & 2 & 5 & 0 & 0 & 0 & 0 & 5 & 12.5 & 1 & 2.5 & 0 & 0 \\
\hline Total & 40 & 10 & 25 & 5 & 12.5 & 5 & 12.5 & 15 & 37.5 & 5 & 12.5 & $\mathbf{0}$ & $\mathbf{0}$ \\
\hline
\end{tabular}

Table (6) cleared that the number and incidence of isolated bacterial strains from uteri of goats was 8 (20\%) Staph. aureus, 5 (12.5\%) Strept. viridans, 5 (12.5\%) Campylobacter fetus, 10 (25\%), E. coli, 4 (10\%) Proteus vulgaris and $0(0 \%)$ Ps. aeruginosa (non purulent uteri) while, in Purulent uteri, they were 2 (5\%) Staph. aureusi, 0 (0\%) Strept. viridans, 0 (0\%) Campylobacter fetus, 5 (12.5\%) E. coli, 1 (21.5\%) Proteus vulgaris and $0(0 \%)$ Ps. aeruginosa. 
Aerobic Bacteria Associated With Endometeritis Of ...

Table (7): The rate of isolated bacterial strains from uteri of goat.

\begin{tabular}{||l||c|c||c|c||c|c||}
\hline \multirow{2}{*}{ Microorganisms } & \multicolumn{2}{c||}{ Total } & \multicolumn{2}{c||}{ Non Purulent uterus } & \multicolumn{2}{c||}{ Purulent uterus } \\
\cline { 2 - 7 } & No. & $\%$ & No. & $\%$ & No. & $\%$ \\
\hline \hline Staph. aureus & 10 & 25.00 & 8 & 20 & 2 & 5 \\
Strept. viridans & 5 & 12.50 & 5 & 12.5 & 0 & 0 \\
Campylobacter fetus & 5 & 12.50 & 5 & 12.5 & 0 & 0 \\
E. coli & 15 & 37.50 & 10 & 25 & 5 & 12.5 \\
Proteus vulgaris & 5 & 12.50 & 4 & 10 & 1 & 2.5 \\
Ps. aeruginosa & 0 & 0.00 & 0 & 0 & 0 & 0 \\
\hline \hline \multicolumn{1}{|c|}{ Total } & $\mathbf{4 0}$ & $\mathbf{1 0 0}$ & $\mathbf{3 2}$ & $\mathbf{8 0}$ & $\mathbf{8}$ & $\mathbf{2 0}$ \\
\hline \hline
\end{tabular}

Table (7) revealed that the number and rate of the isolated bacterial strains from uterus goat (non purulent and purulent uteri) was $8(20 \%)$ and $2(5 \%)$ Staph. aureus, $5(12.5 \%)$ and $0(0 \%)$ Strept. viridans, 5 (12.5\%) and 0 (0\%) Campylobacter fetus, 10 (25\%) and 5 (12.5\%) E. coli $_{s} 4(10 \%)$ and 1 (2.5\%) Proteus vulgaris, and Ps. aeruginosa strains were not isolated respectively.

Table (8): Results of sensitivity test.

\begin{tabular}{|c|c|c|c|c|c|c|c|}
\hline Microorganisms & 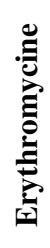 & 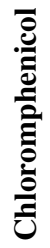 & 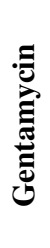 & 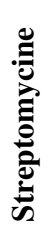 & 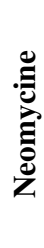 & 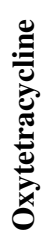 & 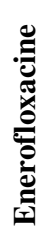 \\
\hline Staph. aureus & + & + & + & + & + & + & + \\
\hline Strept. viridans & + & + & + & + & + & + & + \\
\hline Campylobacter fetus & - & - & + & + & - & - & + \\
\hline E. coli & - & - & + & - & - & - & + \\
\hline Proteus vulgaris & - & - & + & - & - & - & + \\
\hline Ps. aeruginosa & - & - & - & - & - & - & + \\
\hline
\end{tabular}

Kafrelsheikh Vet. Med. J. Vol. 7 No. 1 (2009) 
Table (8) revealed that Staph. aureus and Strept. viridans were sensitive to chloramphenicol, neomycine, oxytetraycline, streptomycin, erythromycine, and enerofloxacine. Proteus vulgaris and E. coli were sensitive to gentamycin and enerofloxacine, Campylobacter fetus were sensitive to streptomycine, gentamycine and enerofloxacincine while, $P s$. aeruginosa were sensitive to enerofloxacine only.

\section{DISCUSSION}

This study revealed that the post mortem examination of uteri from slaughtered 100 sheep and 100 goats in an abattoir appeared 85\% and $15 \%$ and $80 \%$ and $20 \%$ non purulent and purulent uteri, respectively, this incidence of purulent uteri is due to non correct treatment of these animals, this agree with Mahajn and Kotoch(1997), Katoch et al. (1997) and Sokkar et al. (1980).

This study showed that the incidence of Staph. aureus (37.5\%), Strept. viridans (12.5\%), Campylobacter fetus (2.5\%), E. coli $(37.5 \%)$, Proteus vulgaris (20\%) and Ps. aeruginosa (5\%), and Staph. aureus (12.5\%), E. coli (12.5\%), Proteus vulgaris (5\%) in with non purullent and purulent uteri of sheep, respectively. This finding were agreed the results which reported by Sokkar (1980), while, in goats the incidence of Staph. aureus (25\%), Strept. viridans (12.5\%), Campylobacter fetus (12.5\%), E. coli (37.5\%) and Proteus vulgaris (12.5\%). These obtained results agreed with Sokkar et al. (2007).

This study revealed that the rate of isolated bacterial microorganism was $22.39 \%$ (Staph. aureus), $7.46 \%$ (Strept. viridans), $14.93 \%$ (Campylobacter fetus), $22.39 \%$ (E. coli), $11.40 \%$ (Proteus vulgaris) and $2.99 \%$ (Ps. aeruginosa) and (7.46\% (Staph. aureus), $7.46 \%$ (E. coli and $2.99 \%$ (Proteus vuglaris) in non purulent and purulent uteri of sheep. While, in goats, it was $20 \%$ (Staph. aureus), $12.5 \%$ (Strept. virdans), 
Aerobic Bacteria Associated With Endometeritis Of ...

$12.5 \%$ (Campylobacter fetus) 25\% (E. coli) and 10\% (Proteus vulgaris), and 5\% (Staph. aureus), $1.5 \%$ (E. coli) and 2.5\% (Proteus vulgaris) from non purulent and purulent uteri, respectively, these obtained results were smaller with other results which reported by Nizamani et al. (2002) and Azew et al. (2003).

This study investigated that all Staph. aureus and Strept. viridans strains were sensitive to Erythromycin, chloramphenicol, gentamycin, streptomycin, neomycin, oxytetracycline and enerofloaxcin, while, campylobacter fetus strains were sensitive only to gentamycin, streptomycin and enerofloxacin, E. coli strains and Proteus vulgaris strains were only sensitive to gentamycin and enerofloxacin, while, Pseudomonas aeruginosa strain were only sensitive to enerofloxacine. These results of sensitivity test of used antibiotics except enerofloxacine agreed with the results obtained by Shataiov et al. (1985).

Most isolated bacterial microorganisms in this study were resistant to most of used antibiogram due to plasmid and extrachromosal resistance factor, this point cleared by Bailley and Scott (1974).

\section{REFERENCES}

- Azew, O.; Al-Baual, S.M.T. and Zenad, M.M. (2003). Bacteriological and histopathological associated with dystocia in Awassi ewes. Iraqi Journal of Veterinary Sciences 17(1): 154-191.

- Bailey, W.R. and Scott, E.G. (1974). Diagnostic microbiology the $4^{\text {th }}$ edition, The C.V. Mosoby Company.

- Blood, D.C. and Henderson, JA. (1974). Veterinary medicine $4^{\text {th }}$ edition, the English Language Book, Society and Ballere Tindall.

- Cruickshank,R.;Dugina,J.P.;Masmino, B.P.and Swain, R.H.A. (1975). Medical microbiology. The practice of medical microbiology. $12^{\text {th }}$ Ed.,Vol.11.Churchill Living Stone Edinburgh,London and New York. 
- Donkin, E.F. and Boyazogiu, P.A. (2004). Diseases and mortality of adult goats in a south African milk goats herd. South African Journal of Animal Science, 39(1): 254-257.

- Ernest Jawetz, Joseph, L. Melnick and Edward A. Adelberg (1976). Review of medical microbiology. 12 . edition, Lance Medical Publications, Losalton, California.

- Katoch, R.C.; Mandeep-Shanna; Batta M.K.; Joshi, V.B.; Asrani, R.K.; Nagal, K.B.(1997). Investigations on enodmeteritis among sheep and goats. Indian-Veterinary-Journal, 74(6): 365-367.

- Mahajan, A.K. and Katoch, R.C. (1997). Aerobic microbial flora association with enodmeteritis in sheep and goats. Indian Journal of Animal Sciences, 87(4): 290-291.

- Martin, W.B. and Aiken, I.D. (2000). Diseases of sheep 3 edition, the Black well Science.

- Nizamani, A.W.; Khan, T.S.; Siddinui, L.A.; Rind, R.; Laghan, H.H. (2002). Studies of bacteria flora of uteri of slaughtered sheep. Journal of Animal and Veterinary Advances 1(2): 89-91.

- Shataiov, V.F.; Neknaev, E.E.; Knrapkovaskaya, L.P. (1985). Drug sensitivity of bacteria from the genital system of animals. VeterinariyaMoscow, (9): 46-47.

- Sokkar, S.M.;Ahmed,Y.F.;Desouky, H.M.and Soror, A.M.N. (2007). Pathological studies on sheep endometritis. Vet. Med. J. Giza, 55 (1): 131-144.

- Sokkar,S.M.;Kubba, M.A. and Augaloy, E. (1980). Studies on natural and experimental endometritis in ewes. Veterinary Pathology, 17(8): 893-898. 


\section{البكتيريا الهوائية المصاحبة للاتهابات الرحمية للأغنام والماعز المذبوحة بمحافظة كفرالشيخ}

$$
\text { معلعت حامد شعيشع بلير - بمال الدين ابراهيم مزيل }
$$

أجريت هذه الدر اسة بمحافظة كفر الثيخ على إناث الماعز و الأغنام (100 رأس غنم و 100 رأس من الماعز) و هذه الحيو انات ذبحت داخل السلخانة فى الفترة من أول ديسمبر 2008 حتى نهاية

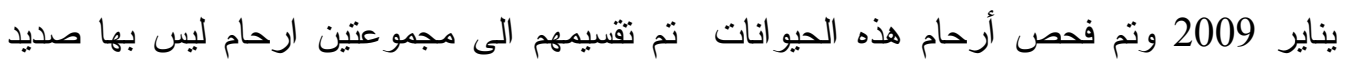

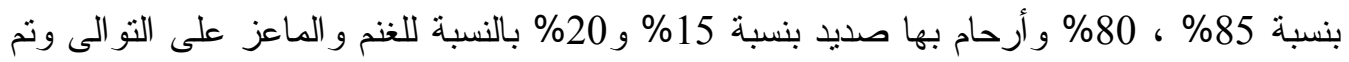
أخذ عينات من عدد 40 غنم وعدد 40 ماعز و التى تثمل العينات المأخوذة من أرحام الغنم و الماعز

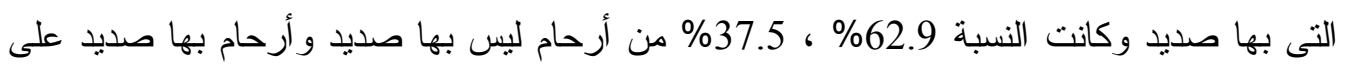
النو الى بالنسبة للغنم ، أما بالنسبة للماعز كانت العينة 50\% ؛

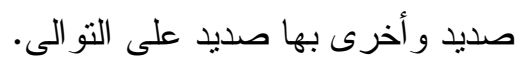
نسبة العترات البكتيرية مقرونة لعدد 40 رأس من أنثى الغنم 50\% مئى ميكروب عنقودى

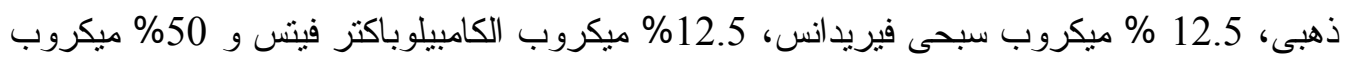
قولونى ة 25\% بروتيس فيرجالس و 5\% ميكروب السيدوموناس اريجنوز ا بالنسبة للغنم ولكن النسبة

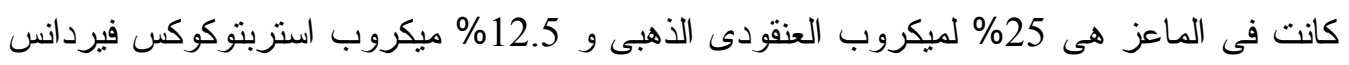
و 12\% كلميلوبكتر فيتس و 37.5\% ميكروب قولونى و 12.5 ميكروب البروتين فولجارس.

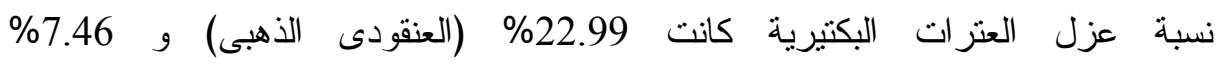
(استربتوكوكس فيردانس) و 14.93\% (كامبيلوبكتر فيتس) و 22.39\% (القولونى الميكروب) و و

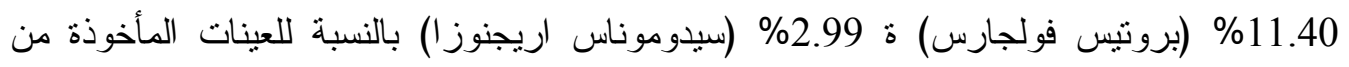
أرحام الأغنام التى لا يوجد بها صديد بينما كانت النسبة لهذه الميكروبات المعزولة من العينات المأخوذة من أرحام الأغنام التى بها صديد كالتالى: 7.46\% (عنقودى ذهبى) ولم يتمكن من عزل التام

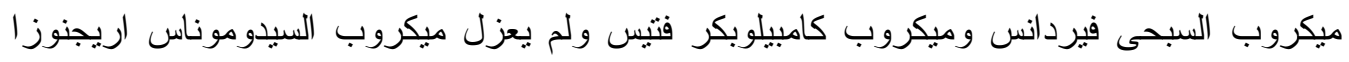
وكانت النسبة للميكروب القولونى (7.46\%) وميكروب البروتيس فولجارس (2.99\%). أيضا كانت

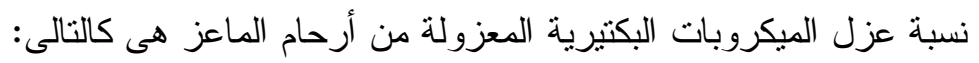


أ- النسبة المعزولة من أرحام الماعز النى ليس بها صديد هى 20\% (العنقودى الذهبى) و 12.5\% (السبحى فريدانس) و 12.5\% (كامبيولوبكتر فيتس) و 25\% (القولونى) و10\% (بروتيس فولجارس) ولم يمكن عزل ميكروب السيدوموناس اريجنوز ا. ب- النسبة المعزولة من أرحام الماعز و النى بها صديد وهى 5\% (العنقودى الذهبى) و 12.5\% (القولونى) و 2.5\% (بروتيس فولجارس) ولم نتمكن من عزل ميكروب السيدموناس اريجنوزا و الكامبيلو بكتر فتيس و السبحى فيردانس.

أضافت هذه الدراس أن كل من المعزولات الأتي: الميكروب العنقودى الذهبى والسبحى فريدانس كانت حساسة لكل من مضاد الإرثرومايسين وكلور امفينكول وجنتاميسين و استربتومايسين ونيومايسين و أوكسىتتر اسيكلين و الانروفلوكساسين. بينما المعزو لات من الميكروب كاميبلوكتر فيتس كانت حساسة لكل من وجنتاميسين واستربتومايسين و انروفلوكساسين ولكن الميكروب القولونى و البروتيس فولدجارس كانت حساسة فقط لمضاد جنتامايسين والأنروفلوكساسين وأوضحت هذه الدراسة أيضا أن المعزول من ميكروب السيدموناس اريجنوزا كانت حساسة فقط لمضاد الانروفلوكساسين ومقاوم لبقية المضادات المستخدمة. 